\title{
The Pesantren Networking In Priangan (1800-1945)
}

\author{
Ading Kusdiana ${ }^{1 *}$, Nina Herlina Lubis ${ }^{2}$, Nurwadjah Ahmad EQ ${ }^{3}$, Mumuh Muhsin $Z^{4}$ \\ ${ }^{1}$ Adab and Humanities Faculty, State Islamic University of Sunan Gunung Djati Bandung. \\ ${ }^{2}$ Culture Science Faculty, and Post Graduate of Padjadjaran University. \\ ${ }^{3}$ Adab and Humanites Faculty, State Islamic University of Sunan Gunung Djat Bandung. \\ ${ }^{4}$ Culture Science Faculty, and Post Graduate Padjadjaran University. \\ *Corresponding Author, Email: adingkusdiana@yahoo.co.id
}

\begin{abstract}
This research is about the networks of pesantren in Priangan from 1800 to 1945. The result shows that along 1800-1945, there were many networks that described the relations among pesantrens in Priangan. There are five networks forms as manifested from those relations. First, the networks among pesantrens, which were formed, are based on scientific relation. They are Pesantren Al-Falah Biru, Pangkalan and Keresek in Garut; Gentur, Kandang Sapi and Darul Falah Jambudipa in Cianjur; Sukamiskin Bandung; and Darul Ulum in Ciamis. Those pesantrens have intellectual relation that pointed to one public figure, namely Syekh Khatib Sambas in Mecca. Second, the networks among pesantrens, which were formed, are based on relative (genealogy) relations. The existence of Pesantren Sumur Kondang, Keresek, Gentur, and Cijawura were the ones that have this relation. Third, the networks among pesantrens, which were formed, are based onmarriage relation. For instance, Pesantren Cidewa with Pagerageung, Pesantren Cipari with Cilame, Cipasung with Gentur Rancapaku, Cijantung with Gegempalan, Sukamiskin with Al-Jawami, and Pesantren Sukamiskin with Cijawura Bandung, were the ones that have this relation. Fourth, the networks among pesantrens, which were formed, are based on the similarities in developing a particular Islamic mysticism (tarekat). The existence of Pesantren Suryalaya which develops Qodiriyah wa Naqsabandiyah mysticism - followed by generating their talqin and Pesantren Al-Falah Biru which develops Tijaniyah mysticism-followed by generating their muqaddam are the ones of this relation. Fifth, the networks among pesantrens, which were formed, are based on the same vision of their movement and struggle against the colonizer. The existence of Pesantren Al-Falah Biru with Samsul Ulum Gunung Puyuh through POII (Persatoean Oemat Islam Indonesia) organization, and Pesantren Cipasung with Sukamanah through Nahdhatul Ulama organization in Tasikmalaya were the ones who struggle against the colonizers of Netherland and Japan.
\end{abstract}

Keywords: Pesantren, Network, Priangan

\section{A. INTRODUCTION}

Pesantren is an important institution in the spread of Islam. It is stated that because of the activities of founding candidates religious teacher, kiyai, or ulama occurred in Pesantren. Usually the students of pesantren after finishing study, they return to their hometown. In their hometown they become religious teacher, become a kiyai who held pesantren again. Thus, pesantren and their kiyai have an important role in the development of public education (Kartodirdjo, 1976).

The process of spread of Islam in Tatar Priangan, in addition to be related to the presence of the figure of a kiyai and his student, one thing that can not be separated from the existence of an interpesantren network is as an institution which become a place of the kiyai and his student, where through agencies which have been established they are actively involved in the spread of Islam, 
particularly through the process of transmission and transformation of Islamic scholarship in order to improve the community understanding of the religious.

In the 19th century along with the spread of Islam is increasingly widespread in the Priangan, pesantren as a base spread of Islam began to emerge. Based on the first survey of the Dutch government in 1819 mentioned that traditional institutions have been widely scattered in some places are located in rural areas (Haedar, 2004).

Although there is no statistical data that shows how many pesantren scattered in Priangan in the time of Dutch East Indies government and the occupation of Japan, but the existence of pesantren which are organized in networks became a matter of concern for the Dutch East Indies government, especially after the opening of the Suez Canal in 1869 which encourages Muslims to perform Hajj (Kartodirdjo, 1984; Yatim, 1997). The same precautions indicated also by the Japanese occupation government. Although Japanese occupation government was not long enough, which for more or less three and a half years but they are also constantly aware of the existence of pesantren.

Networking is important to study because from 1800 to 1945 pesantren has been spreaded in the Priangan and it is found that they are still exist and can be categorized as an old pesantren. Among one pesantren with the other still have a close relationship, there is even a tendency has prompted the creation of an inter-pesantren network. However, in reality it is still missing from the research efforts conducted specifically, insightful, and thorough.

The research method used in this researchis a methodof historical research, the method of research which studies events in the past in order to make there construction of the past systematically and objectively by collecting, evaluating, verifying, and synthesizing evidence to uphold facts and obtain the correct conclusion. In practicethis methodis done by going through the stages heuristic, criticism, interpretation, and historiography (Garaghan, 1946; Gottschalk, 1986).

\section{B. METHODOLOGY}

This research uses history approach. The type of the research is descriptive and verificative, while the method used both descriptive and explanatory survey. Investigation type is casualty and time horizon in cross sectional. This paper also used comparative research methods. Comparative research is a method of research that is comparing. Here still the same object to different places more than one, or in a different time.

\section{RESULT AND DISCUSSION}

\section{Pesantren Deployment in Priangan Region on the Period of Years 1800-1945}

Pesantren was usually emerged in the civilian's life because of the awareness of an obligaton of Dakwah Islamiyah; that is the obligation not only to spread and to progress the Islamic teaching but also to generate ulama and Da'i who appear in human's daily life. The existence of pesantren in Priangan, which appeared on $19^{\text {th }}$ century until the fifth years on the fourth decade of twentieth century, had reached the significance number on its' spread on every places. It was noted that there were many pesantren: Pesantren Biru, Sumur Kondang, Kresek, Sukaraja, Cipari, Pangkalan and Darussalam which were located in Garut (Basri, 1977:2; Mas'udi et al., 1986:76; Arifin, (without year): 1-2; Lilis, interview, 13 th of January 2010; Affandi, interview, $28^{\text {th }}$ of July 2011, Ikyan, interview 12th of December 2011). 
Furthermore, there were Pesantren Gentur, Kandang Sapi, and Jambudipa in Cianjur. Then, there were Pesantren Minjahul Karomah Cibeunteur, and Pesantren Miftahul Huda Al-Azhar Citangkolo in Banjar. Besides that, in Bandung, there were many Pesantren that can be found like Pesantren Mahmud, Sukapakir, Sukamiskin, Al-Bidayah Cangkorah, Al-Asyikin, Islamiyah-Cljawura, Cikapayang, Sindangsari Aljawami, Al-lttifaq, Pesantren Persis, Palgenep, Hegarmanah, Cigondewah, Sinarmiskin, Sadangsari and Cijerah (Ismatullah, interview, 12 th of February 2010; Komarudin, interview, 12 ${ }^{\text {th }}$ of February 2010; Anam, 12 ${ }^{\text {th }}$ of February 2010; Wadud, 19th of January 2010; Aziz, 15th of July 2011; Herlina et al., 2011: 41).

In Sumedang, Pesantren Asyrofudin, Pagelaran Sumedang-Subang and Darul Hikmah had been represented the existence the Pesantren deployment in the area. The next pesantren are Pesantren Kudang, Suryalaya, Cilenga, Cintawana, Mathlaul Khair, Assalam, Bahrul Ulum, Sukahideung-Sukamanah and Cipasung could be found in Tasikmalaya (Rosidi et al., 2000: 513514; Sanusi, interview in 30th of July 2011; Yahya, 2006: 14\& 16; Pradja and Anwar, 1990: 199; Siswanto et al., 1986: 35, 38-39 \& 82; At-Tarmizai and Yazid, 2008: 2-3). Rustam, interview in 18 of January 2010; Fuad, interview in $2^{\text {nd }}$ of September 2011; Rosidi et al., 2000: 514).

Meanwhile, Pesantren Darul Ulum, Pesantren Cidewa/Darussalam, Pesantren Al-Qur'an Cijantung, Pesantren Miftahul Hoer, Pesantren al-Fadhiliyah (Petir) are five Pesantren, which spreaded in Ciamis. Then, Pesantren Cantayan, Genteng and Syamsul Ulum Gunung Puyuh wrere located in Sukabumi (Abdullah, interview in 30th of January 2010; Mansur, interview in $18^{\text {th }}$ of January 2010; Rohim, interview in 19th of January 2010; Ainusyamsi, interview in $18^{\text {th }}$ of August 2011; Department of Religious Affair (Departemen Agama R.I.), 2001: 110; Haris, interview in 14 th of December 2011).

All of the pesantren that have been mentioned above, were the pesantren which were located in Priangan region on $19^{\text {th }}$ century until the fifth years on fourth decade on twentieth century. Those pesantren could be said as big and inspirational pesantren on their age. Besides, the existences of those pesantren were the well-known pesantren that could be found in Priangan region. The information above was the information about pesantren, which were located in Priangan region from year 1800 until the middle period on fourth decade on twentieth century. To make clear, during this period even there were no statistical data that showed the number of those pesantren, however, the existing pesantren had shown their role and the significance number.

\section{a. Pesantren Network in Priangan (1800-1945)}

The Network of Knowledge of Pesantren on 19th Century until Fifth Years on Fourth Decade of Twentieth Century. If we noted the existence of pesantren in Priangan region those pesantren had deeply connected one and each other. That was happened because those pesantren had a relational bound of one and each other like scientifical bound, genealogical bound, marital bound, the same vision of heroic movement against the imperial, and also the same tareqat which had been developed in certain pesantren and then followed by the other pesantren.

From all the explanation of the connecting relation of knowledge among the pesantren in Priangan region, there were many notes that scientifically pesantren in Priangan on $19^{\text {th }}$ century until fifth years on fourth decade of Twentieth century, had a connection with five pesantren, those are: pesantren Mahmud Bandung, Pesantren Bangkalan Madura, which was led by Syekh Khalil (K.H. Muhammad Khalil), Pesantren Tebu Ireng Jombang of East Java which was led by K.H. Hasyim Asy'ari, Pesantren Ciwedus Kuningan and Pesantren Kudusiyah. 
It was needed to be described, that scientifically, the existence of pesantren in Priangan region in general has connection with two pesantren: Pesantren Bangkalan and Tebu Ireng. However, in Bandung and Sumedang there are many pesantren that did not have scientific connection with pesantren in Java Island on the east side those are Pesantren Mahmud, Pesantren Persatuan Islam (Persis) and Pesantren Asyropudin. Pesantren Al-Bidayah Cangkorah, Al-Asyikin, Cikapayang, Al-Itifaq, Mathlaul Anwar-Palgenep, Hegarmanah, Cigondewah, Sinarmiskin, Sadangsari and Cijerah themselves are pesantren which were assumed had connection in science with Pesantren Mahmud. Pesantren Mahmud itself did not have a scientific relationship with Pesantren Bangkalan and Tebu Ireng. This could be understood because these Pesantren had been existed in Bandung before Pesantren Bangkalan and Tebu Ireng were developed. Thus, Pesantren Mahmud had been existed earlier from both pesantren in Java Island on the East side. Next, there was no information about the next generation of Pesantren Mahmud who learned from those two pesantren, and neither did they.

However, with the unscientifical-relation with Pesantren Persis and Asyropudin with the other pesantren in Priangan region, because Pesantren Persis were taught and established even more by ulama of Persis which organized as the organization of Islamic Union (Persatuan Islam), meanwhile with Pesantren Asyropudin, the keeper learned to Pesantren Kudusiyah (Kudus) than learned from the pesantren around.

Interesting to observe, that the pesantren led by Syekh Khalil Bangkalan (KH Muhammad Khalil) and Pesantren Tebu Ireng Jombang led KH Hasyim Asya'ri, both scholarly ties with Syekh Nawawi Al-Bantani, a famous cleric of Banten because they have learned to him while he was in Mecca. Syekh Khalil and K.H. Hasyim Asy'ari they inherit many of the scientific knowledge of Syekh Nawawi Al-Banteni, even Syekh Khalil in addition to inheriting the world of science, he was also prominent in the spiritual world, which is as murshid or caliph Tarekat Qodiriyah wa Naqsyabandiyah (Suprapto, 2009)

Syekh Nawawi Al-Bantani himself scholarly relationship with Syekh Khatib Sambas because he had studied to Syekh Khatib Sambas in Mecca he even learned the Order Qodiriyah. Syekh Ahmad Khatib Sambas was the scholar and renowned spiritual Mecca in the 19th century. After become a great scholar he settled in Mecca, and opened halaqah own to nurture students who study Islamic sciences. Among the famous students who came from the island of Java is Syekh Al-Nawawi Bantani, Syekh Mahfud At-Tarmisi, Syekh Abdul Karim Al-Bantani, and Syekh Muhammad Khalil (Hurgronje, 1888; Hurgronje, 1890; Hurgronje, 1931; Gobbe and Adriaanse, 1993; Suprapto, 2009).

\section{Description:}

1. Green letters show schools that have a network of science with the leadership of Syekh Khalil Pesantren Bangkalan (KH Muhammad Khalil) and Tebu Ireng Pesantren leader KH Hashim Ash'ari and then geared towards Syekh Nawawi Al-Bantani and Syekh Al-Khatib Sambas.

2. Blue letters show schools that have a scientific network to Pesantren Ciwedus to $\mathrm{KH}$ Shobari.

3. Red letters show schools that have a scientific network with Pesantren Kudusiyah-Kudus

4. Black letters show schools that have a scientific network with Pesantren Mahmud.

5. Yellow letters show schools that do not have a scholarship to pesantren network in Priangan 
Sources: Hurgronje, 1888: 362; Hurgronje, 1890: 92-105; Hurgronje, 1931: 268-290; Gobbe and Adriaanse, 1993: 1287; Rohim, interview on January 19, 2010; Ministry of Religious R. I., 2001: 97-98; Noer, 1991: 96.102; Lathifulhayat, 2008: 110; Iskandar, 1999: 166; Muhyidin, interview dated March 13, 2010; Sulaeman, interview dated March 13, 2010; Komar, an interview on March 13, 2010 ; Wanta, 1997: 3-16, 1927; Sulasman, 2008; Tohir, interview on January 30, 2010; Solehudin, interview on January 12, 2010; Abdullah, interview on January 30, 2010; Aziz, interview on July 15, 2011; Hamid, interview dated July 15, 2011; Rufaidah, 2003: 137-139, 147-148; Kholik, interview on December 26, 2012; Mansur, interview on January 18, 2010; Ainusyamsi, interview dated August 18, 2011; Hasan, interview on January 18, 2010; Sudjai , interview on January 18, 2010; Misbah, interview on July 28, 2011; Bunyamin, interview on July 28, 2011; Mas'udi et al, 1986: 38-39, 50, 67-68; Rustam, interview on January 18, 2010; Yahya , 2006: 6, 14-16, 23; Fuad, interview on 2 September 2011; Rosidi, 2000: 513-514; Hasan, interview on January 18, 2010; Anonimous, t.th.: 1-2; Saefullah, interview date 2 September 2011; Sanusi, 1990: 94-95; Siswanto et al., 2005: 7-8, 10, 23; Anam, interview dated 12 February 2010; Jauhari, interview on January 12, 2010; Sanusi, interview, July 30,2011 ; Wadud, interview on January 19, 2010; Munandar, interview dated 12 February 2010; Komarudin, interview dated 12 February 2010; Anam, interview dated 12 February 2010; Affandi, interview on July 28, 2011; Lilis, interview on January 13, 2010; Ikyan, interview on December 12, 2011; Hanif, interview date July 28, 2011)

\section{b. Marriage Network}

The formation of pesantren network in Priangan was not only through scientific or intellectual ties through the transformation and transmission of religious knowledge of a Kyai to his student but also through on a marriage involving two large families of pesantren.

The emergence of inter-pesantren network bound by marriage; create a strong relationship that can occur through a marriage between the sons of a Kyiai a particular pesantren with the daughter of a Kiyai from other pesantren. This matter happened in Priangan between Pesantren Cidewa or Pesantren Darussalam Ciamis with Pesantren Pageurageung Tasikmalaya, Pesantren Cipari with Pesantren Cilame, Pesantren Cipasung which was founded by Kiyai Ruhiyat still has a close relationship with Pesantern Gentur Rancapaku, Pesantren Sukamiskin Bandung with Pesantren Bait Al-Arqam Bandung, Pesantren Sukamiskin with Pesantren Cijawura, Pesantren Sindangsari Al-Jawami Bandung with Pesantren Sukamiskin, Pesantren Cijantung have marital relations with Pesantren Gegempalan Panjalu

Diagram 2

Marital Network between Pesantren Cipari And Pesantren Cilame

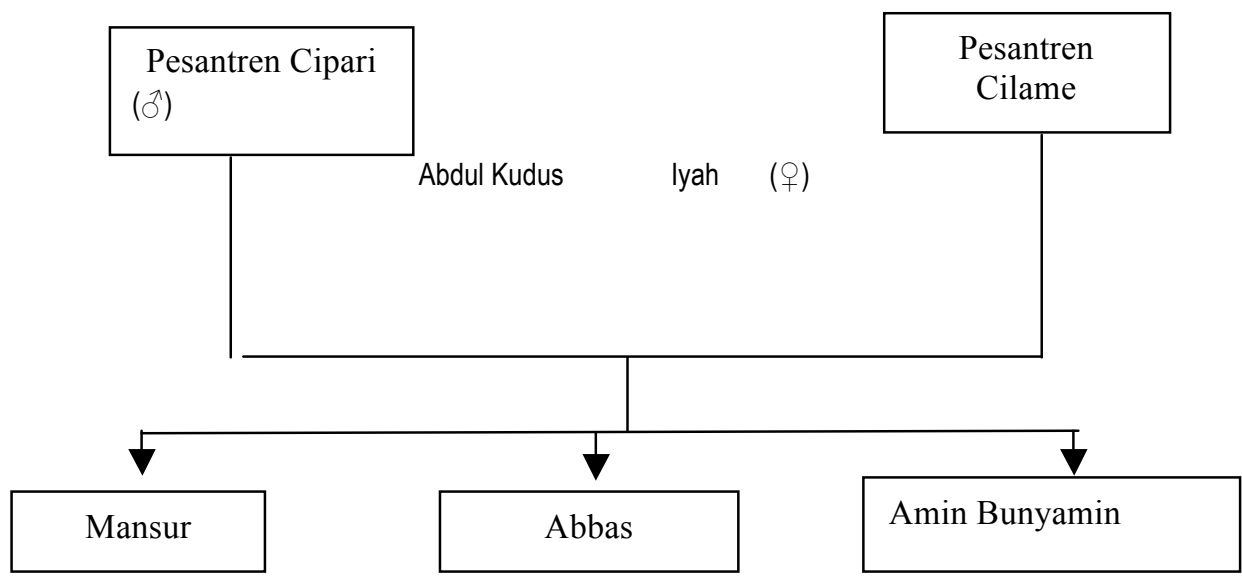

Source: Bunyamin, interview on July 28, 2011. 
Diagram 3

Marital Network

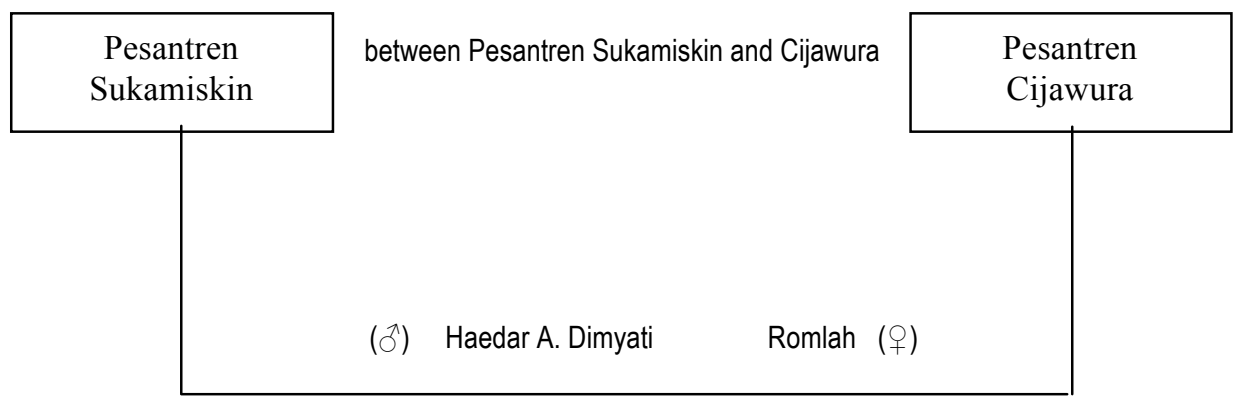

Source : Aziz, interview on July 15, 2012

Such is the picture of inter-pesantren network based on marital relationship that occurred in the period of the 19th century up to the fourth decade of the 20th century.

\section{c. Geneological Network/Kinship}

Kinship for kiyai in pesantren plays comparatively a more powerful role in shaping the behavior of economic, political and religious. In the tradition of pesantren life, from one generation to its successor, kiyai always pay special attention to the education of their own children to be a substitute for leading pesantren institutions. If a kiyai has more than one son, usually the eldest son he expects to replace his position as leader of pesantren after he died, while the other sons are more trained to be able to set up a new pesantren, or can replace his father in-law position that most also is the leader of pesantren (Dhofier, 1982).

As with Pesantren Sumur Kondang in Garut which still have a geneological relationship with Pesantren Pamijahan that built by Syekh Abdul Muhyi. According to Usman Affandi, Kiyai Nuryayi who was the founder of the Pesantren Sumur Kondang well still havea geneological relationship or blood relationship with Syekh Abdul Muhyi Pamijahan. According to oral tradition conveyed from generation to generation, that the existence of Kiyai Nuryayi who is also seen as an ancestor that gave birth to the founding generation of Pesantren Keresek is a descendant of Syekh Abdul Muhyi Pamijahan (Lilis, interview, January 13, 2010; Affandi, interview on July 28, 2011).

Pesantren Keresek has geneological ties with Pesantren Sumur Kondang, because Kiyai Tobri who regarded as the founder of pesantren Keresek was the descendant of Kiyai Nuryayi, founder of Pesantren Sumur Kondang. The geneological relationship of Kiyai Tobri and Kiyai Nuryayi can be obtained from the tracking genealogy, it stated that Kiyai Nuryayi has a son named Kiyai Nursalim (Muhammmad Salim). Kiyai Nursalim (Muhammad Salim) has a son that is Kiyai Nurhikam. All threewere the founder of Pesantren Sumur Kondang before the establishment of Pesantren Keresek. Furthermore, Kiyai Nurhikam has a son that is K.H. Tobri (Lilis, interview, on January 13, 2010; Affandi, interview on July 28, 2011).

From this, it can be traced the geneplogically relationship or kinship between the Pesantren Sumur Kondang with Pesantren Keresek. Apparently, at the time still leading Pesantren Kiyai Nurhikam Sumur Kondang, Kiyai Tobri continued leadership in the pesantren was not Sumur Kondang but he established new schools that would be a pesantren named Keresek. Pesantren Keresek in Garut still had an alliance with the Islamic School in Cianjur Gentur as founder of Pesantren Keresek, namely the founding Kiyai Tobri Pesantren Gentur, said the Kiyai Muhammmad when 
viewed from both the family genealogy is a descendant of the founder of the Islamic School Sumur Kondang; Kyai Nuryayi.

Kiyai Muhammmad Said to be the founder Pesantren Gentur is derived from Garut. He was the son of the Kiyai Nuryayi, founder of the Pesantren Sumur Kondang. Please note that after the leadership of Kiyai Nuryayi, Pesantren Sumur Kondang in Garut his leadership by Kiyai Muhammad Said, but by the other brother is Kiyai Nursalim (Muhammmad Salim). Kiyai Muhammad Said himself then more interested in establishing new schools by moving to Cianjur and establish new schools called Pesantren Gentur (Lilis, interview, on January 13, 2010; Affandi, interview on July 28, 2011).

However, it should also be emphasized that the presence of Pesantren Gentur in Cianjur certainly earlier than Pesantren Keresek. Pesantren Gentur in Cianjur still contemporary with the founders Pesantren Sumur Kondang Garut since it was founded by his own Kiyai Nuryayi, Kiyai Muhammmad Said, while pesantren founded by the great-grandfather Keresek new (fourth generation) from Kiyai Nuryayi, the Kiyai Tobri in 1887.

That relationship between the Pesantren Gentur and Pesantren Keresek. The relationship between Pesantren Gentur with Keresek, if drawn conjunction of the second generation, still has ties siblings, because the Kiyai Muhammmad Said with Embah Maklum and the Kiyai Nursalim grandparent understand and grandfather who were both Kiyai Tobri, as the founder of Islamic School is Keresek siblings (Lilis, interview, dated January 13, 2010; Affandi, interview on July 28 , 2011).

The relationship between the Pesantren Gentur and Pesantren Keresek, if you see the look of the figure Kiyai Muhammmad Said second-generation offspring Kiyai Nuryayi and a Kiyai Tobri associated with Kiyai Nuryayi who is a descendant of the fourth generation, the relationship between the two schools was a grandfather and his grandson.

This relationship between Pesantren Gentur geneologis and Keresek. With Pesantren Sumur Kondang own, Pesantren Gentur have geneologically father and son relationship, while Pesantren Sumur Kondang with Pesantren Keresek with ties geneologis great-grandfather.

Between Pesantren Keresek with Pesantren Cijawura Bandung established Kiyai Muhammad Burhan still has a relationship geneologis. Indications are the relationship between Pesantren Keresek geneologically with Pesantren Cijawura, can be traced to the existence Kyai M. Burhan was born in Keresek in 1901. He is the grandson of the founder of the Islamic School Keresek, the Kyai Tobri. Thus the relationship between the Pesantren Cijawura and Pesantren Keresek is the grandfather to the grandson (Herlina et al., 2011: 125).

If with the Pesantren Keresek, Pesantren Cijawura geneologically still have a relationship, it can be ascertained that between the Pesantren Cijawura and Gentur was actually still have a relationship geneologis despite being somewhat distant. However please note that during the wanderings in search of knowledge, before leading Pesantren Cijawura Muhammad Burhan studied at Pesantren Keresek, Pesantren Sukamiskin, Pesantren Gentur and Pesantren Sempur Purwakarta. Thus geneologis and intellectually between Pesantren Keresek Garut, and Pesantren Cijawura Bandung actually still have a relationship, both genealogy and scholarly / intellectual.

In addition to Pesantren Gentur and Keresek relationships in genealogy, other schools in the area that still has Priangan geneologis relationship to each other is Pesantren Al-Falah Biru with 
Pesantren Ciparay Bandung. Pesantren Al-Falah Biru with Pesantren Ciparay still has a father-son relationship geneologis, as founder Pesantren Ciparay, namely Syekh Iming Bunyamin (Kyai Iming) is still a child of Kiyai Asnawi Kafrawi Faqih (Ikyan, interview on December 12, 2011; Hanif, interview on July 28, 2011).

After the death of Kiyai Asnawi Kafrawi Faqih, Pesantren Al-Falah Biru followed by a Kiyai Badruzaman. When led by the Kiyai Badruzaman relationship between the two schools are brother and sister, as well as teachers and students. Said to have a brother and sister relationship as Kiyai Badruzaman is the younger brother of the Kiyai Iming Bunyamin. Kiyai Badruzaman himself, other than his father had studied, he has also been studying religion by studying with his brother in Pesantren Ciparay (lkyan, interview on December 12, 2011; Hanif, an interview on July 28, 2011).

Geneologically the relationship that occurs between schools that one with the other schools in Priangan the area occurred between Pesantren Cipari and Pesantren Darussalam. Kiyai Harmaen as the successor to the leadership post Cipari Youngest Grandmother (Kiyai Zaenal Abidin), have four children, namely Abdul Kudus, Joseph Tauziri, Bustomi and Siti Quraisyin (Bunyamin, interview July 28, 2011).

Kiyai Abdul Qudus is a person who continued leadership in the Pesantren Cipari after death Kiyai Harmaen. Kiyai Yusuf Taujiri although never together as a Kyai Cipari manage Pesantren Abdul Qudus, in his journey turns out he was more interested in establishing schools that are built upon its own initiative alone, so in 1939 he founded the Pesantren Darussalam Wanaradja Garut.

From the description that has been put forward, including Pesantren Cipari and Pesantren Darussalam still have family ties or close geneologis. Founder Pesantren Darussalam and Pesantren Cipari caregivers after the death of Kiyai Harmaen, they are brother and sister who together have a vision to develop and promote Islamic Religious symbols of education through schools.

Furthermore, the Pesantren Sukamanah and Pesantren Sukahideung. Pesantren Sukamanah still geneologis or familial ties with the founder of the Pesantren Sukahideung because K.H. Zainal Mustafa was still a close with the founder Pesantren Sukahideung, the K.H. Zainal Muhsin. K.H. Zainal Muhsin nothing else is cousin brother of K.H. Zaenal Mustofa as wives K.H. Zaenal Mustofa sister children of Hj. Atikah (Fuad, interview on September 2, 2011)

From the relationship geneologically between pesantren contained in Garut and Tasikmalaya, next is to trace the connections that are geneologis inter-pesantren in Sukabumi. In Sukabumi there are some schools that still have a relationship geneologically. Among Islamic schools that are Pesantren Cantayan, Cisaat, Tile Babakan Sirna, and Samsul Ulum Gunung Puyuh Sukabumi.

Pesantren Cisaat Sukabumi still had an alliance geneologically with Pesantren Cantayan. The trace of Pesantren Cisaat Sukabumi with Pesantren Cantayan of the fact that Kiyai Nahrowi, founder of the Islamic School is the son of the founder Pesantren Cisaat Cantayan, Kiyai Yasin. From the description actually among schools with Pesantren Cantayan with Cisaat still have a close relationship because the two are still bound by the child's relationship with his father (The Ministry of Religious Affairs, 2001).

Likewise with Pesantren Samsul Ulum with Pesantren Cantayan Gunung Puyuh. Still a link geneologically close. If traced between Pesantren Samsul Ulum with Pesantren Gunung Puyuh Sukabumi Cantayan geneologically still have a relationship, because its founder, K.H. Ahmad 
Sanusi was Kyai Abdurakhim, son of the founder Pesantren Cantayan, is Kiyai Yasin (Wanta, 1997; Anonymous, 2009:).

Pesantren Gunung Puyuh Samsul Ulum and Pesantren Cisaat geneologically ties because as the founder of the Islamic School Samsul Ulum, the K.H. Ahmad Sanusi is the nephew Kiyai Nahrowi, founder of the Pesantren Cisaat. Kiyai Nahrowi is the uncle of K.H. Ahmad Sanusi, founder of the Pesantren Cisaat, as Kiyai Abdurakhim the father of K.H. Ahmad Sanusi is the brother of the Kiyai Nahrowi (Wanta, 1997; Anonymous 2009).

Diagram. 4

Geneology Network of Pesantren Sumur Kondang, Gentur, Keresek, and Cijawura

P. Pamijahan

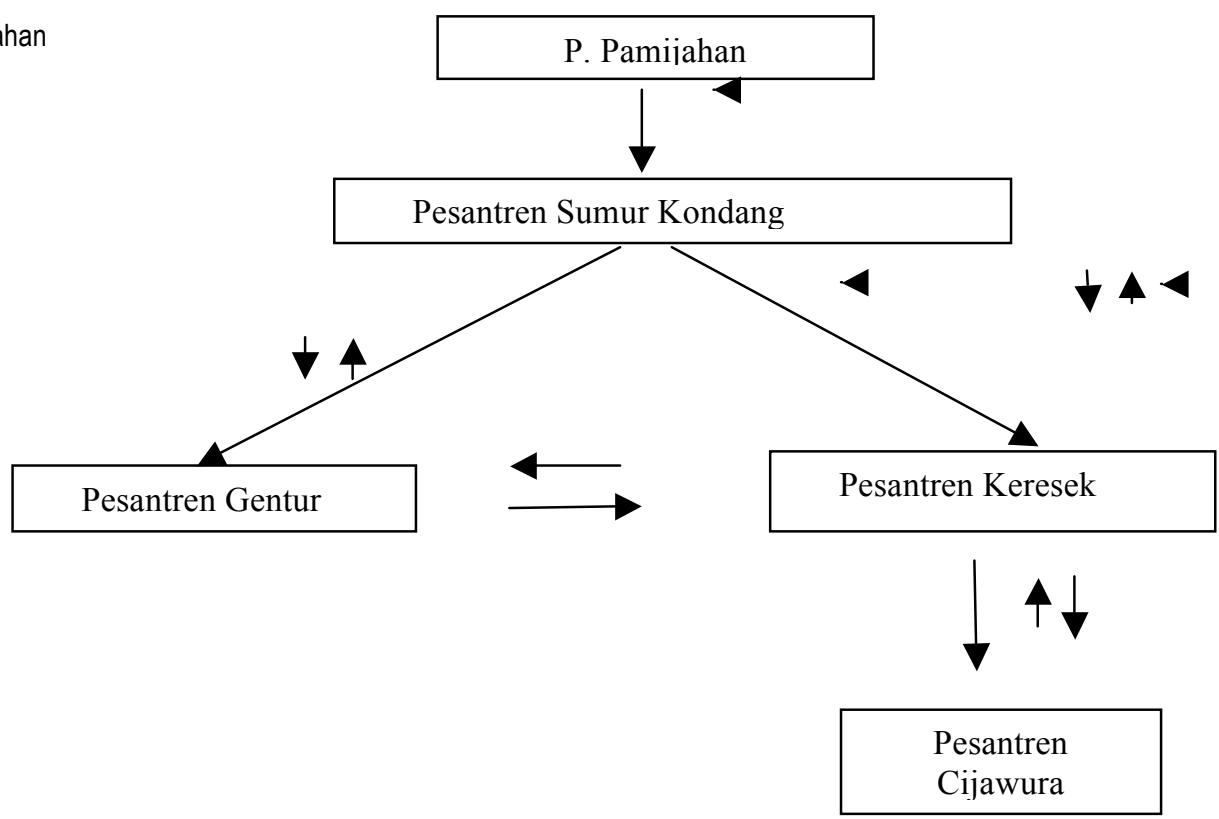

Source: Lilis, interview, on January 13, 2010; Affandi, interview on July 28, 2011.

Tile Pesantren Babakan Sirna established K.H. Ahmad Sanusi before Pesantren Samsul Ulum establish a relationship geneologically with Pesantren Cantayan and Pesantren Cisaat since founding it, namely K.H. Ahmad Sanusi was the son of the Kiyai Abdurakhim and brother of the Kiyai Nahrowi. Finally, connecting to it to say that between Pesantren Cantayan, Pesantren Cisaat and Tile Babakan Sirna / Samsul Ulum Gunung Puyuh, all three cannot be separated by Pesantren Cantayan.

The next phenomenon later was related to the happened among pesantren geneologis rapport between Hoer Miftahul Pesantren and Pesantren Al-Fadhiliyah in the region Ciamis. Pesantren Miftahul Hoer geneologically still has ties with al-Fadhiliyah Pesantren for the second founder of the school is the sister. On the relationship between the siblings to Pesantren Miftahul Hoer with Al-Fadhiliyah, citing a statement conveyed M. Smith Solehudin between Kiyai Sulaeman Kurdi, founder of the Islamic School Miftahul Khoer with Ahmad Komarudin, the founder of Al-Fadhiliyah Pesantren; they are brother and sister (Solehudin, interview on January 12, 2010).

When viewed from geneology with Pesantren Al-Fadhiliyah and Darul Ulum Petir, Pesantren Miftahul Hoer also still has close family ties as the founder of the founder of the Pesantren 
Miftahul Hoer with Pesantren Al-Fadhiliyah are brother and sister. While hubungannnya the Pesantren Darul Ulum is the uncle (Solehudin, interview on January 12, 2010).

That relationship geneologically happened among pesantren Priangan region during the period.

\section{d. The Networks among Pesantrens, which were formed, are Based on the Similarities in Developing a Particular Islamic Mysticism (Tarekat).}

Related to the existence of a network of schools based institute equality, between the 19th century until the fourth decade of the 20th century in the region there has been Priangan among pesantren rapport developed by the equality congregation in Islamic Pesantrens that followed another.

For example, Pesantren Al-Falah Biru has a network of congregations in the equation of the Al-Falah Islamic School, Darul Falihin, Al-Asyariyah Cimencek, Al-Hidayah Islamic School Al-Manar, and Singajaya in Garut as Kiyai Badruzaman develop Tijaniyah congregation distributed to some pesantren. During Sheikh Badruzaman, Pesantren has become the center of the development of the Order Tijaniyah. In developing Tijaniyah congregation, he raised a few representatives in some of these areas Kiyai Muhtar Ghozali at Pesantren AlFalah, Kiyai Ma'mun, community leaders and clerics in Samarang (Garut), Kiyai Endung (Ulama in Cioyod-Cibodas Garut), Kiyai Imam Abdussalam (Scholars and Leaders Pesantren Darul-Falihin Ciheulang Bandung), Kiyai Mahmud (Ulama in Padalarang Bandung) and Kiyai M. Fariqi (Ulama in Pekalongan Central Java) (Badruzaman, 2011; Ikyan, interview on December 12, 2011; Hanif, an interview on July 28, 2011).

Contemporary Pesantren Al-Falah Garut and be the congregation spread Tijaniniyah is Pesantren Asyariyah Cimencek who cared Kiyai Mamun, Pesantren Cioyod who cared Kiyai Endung Muslih, Pesantren Al-Hidayah who raised Kiyai Komarudin, Pesantren Al-Manar who raised Kiyai Ahud Satari, and Pesantren Singajaya who raised Kiyai Ghazali. Additionally during its leading, Kiyai Badruzaman've raised some Muqaddam in different regions to foster students Tijaniyah in their respective areas as Kiyai Muhtar Ghazali and Kiyai Bahrudin (still in Pesantren Biru), Kiyai Surur at Pasir Wangi, Kiyai Mahmud at Sangkan, Kiyai Masum at Cisaar-Bandung, and Kiyai Masduki in Tarogong (Badruzaman, 2011; Ikyan, interview on December 12, 2011).

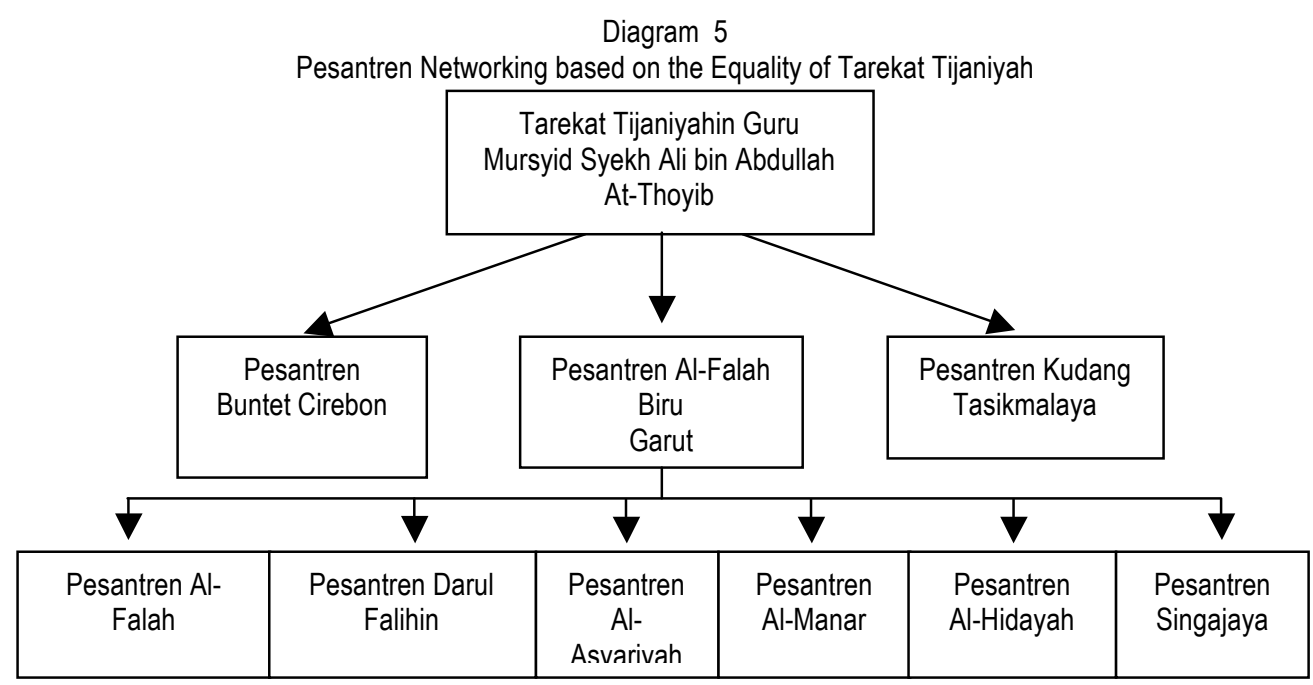

Source: Badruzaman, 2011: 243; Ikyan, interview dated 12 Desember 2011; Hanif, interview dated 28 Juli 2011. 
In addition to Pesantren Al-Falah Biru Garut, other schools can put forward is Pesantren Suryalaya Tasikmalaya. Pesantren Suryalaya is to develop Tarekat Qodiriyah wa Naqsabandiyah. In its introduction, Pesantren Suryalaya with Tarekat Qodiriyah wa Naqsabandiyah Abdullah Mubarak begins with activity in studying in Pesantren Trusmi Cirebon.

After accepting a position as a teacher murshid Tarekat Qodiriyah wa Naqsyabandiyah of Syekh Tolhah bin Talabudin in Pesantren Trusmi Cirebon, Syekh Abdullah Mubarak successor of leadership Tarekat Qodiriyah wa Naqsabandiyah in the Tasikmalaya. He also received guidance tarekat knowledge and tabaruk to Syekh Khalil Bangkalan Madura and even obtain a special certificate of Bani Hashim (Sanusi Ahmad., 1990; Mulyati, 2004; Siswanto, 2005)

Since the time of Syekh Abdullah Mubarak, Pesantren Suryalaya has become the center of development Tarekat Qodiriyah wa Naqsyabandiyah a disc in the eastern region, precisely in Tasikmalaya. In developing Tarekat Qodiriyah wa Naqsyabandiyah so it can be accepted by the community, in addition to taking steps to hold a good relationship with the indigenous elites, Syekh Abdullah Mubarak also good lines of communication with some of the schools by raising his deputy in some schools that are in the surrounding area.

Among the representatives was appointed talkin Kiyai Abdullah bin $\mathrm{H}$. Sanusi, the head of Pesantren Dayeuhkolot Bandung. Furthermore Kiyai Usman Soemantapura, head of Pesantren Cisayong; Kiyai Nadjmudin head of Pesantren Salopa; Kiyai Ahmad Ali Hidayat, head of Pesantren Ciawi in Tasikmalaya and K.H. Abdullah Faqih head of Pesantren Cinambo Talaga-Majalengka (Siswanto, 2005; Arifin, 2005).

Pesantren Networking Based on Equality on Tarekat Qodiriyah wa Naqsabandiyah

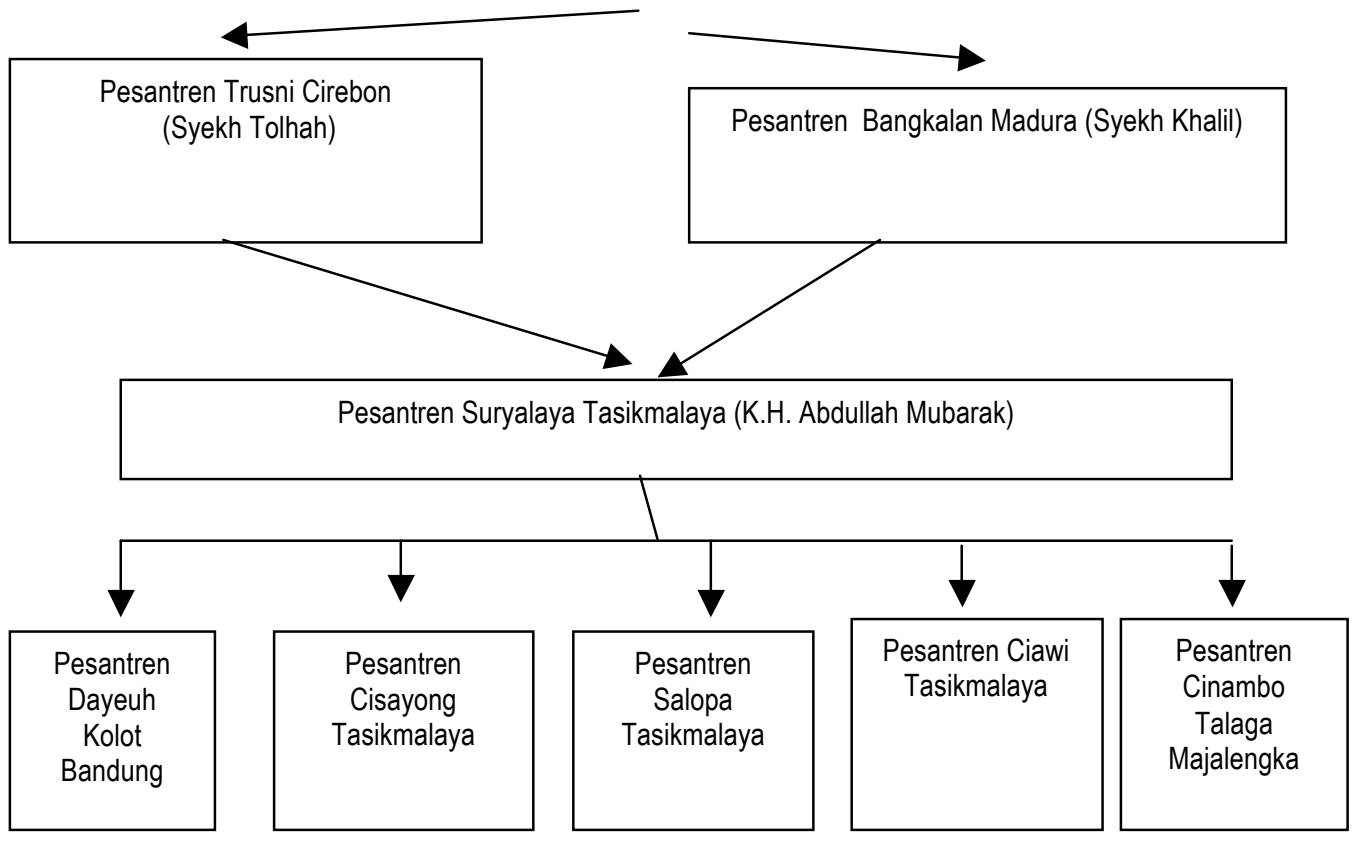

Sumber : Siswanto, et al., 2005; Arifin, 2005. 


\section{e. Network Activity Based Vision Movement and the Struggle Against Invaders}

Pesantren have a role in the attempt to instill values of national consciousness as well as making schools as "the place and the base" of the resistance in the practices against the Dutch and Japanese imperialism in the region Priangan.

It is interesting to observe that the Pesantren Al-Falah Biru with Pesantren Samsul Ulum Gunung Puyuh Sukabumi have a network to work together in opposition to the occupation. In the attempt to realize the struggle that K.H. Badruzaman many support measures K.H. Ahmad Sanusi in setting up an organization called Persatoean Oemat Islam Indonesia (POII) in 1944 as a continuation of the organization of Al-Ittihadiyatul Islamiyah (All) in order to bind the clergy in a container, which had previously been frozen (Wanta, 1997 lkyan, interview on December 12, 2011; Badruzaman, 2011; Adnan, an interview on December 13, 2012).

K.H. Badruzaman put POII sympathetic towards the establishment where KH A. Sanusi one of the managers. Activities POII though hampered by the difficulty of communication and transportation / travel, but can still walk. By utilizing the general assemblies in the branches and the mediation of print media at-Tablighul Islami (name of organ / POll official magazine), K.H. Ahmad Sanusi had visited the area Cianjur, Purwakarta, Bandung (Cililin-Gunung Halu), Garut, Tasikmalaya with PB sharing. At the time of this visit K.H. Badruzaman communicate with K.H. Ahmad Sanusi (Wanta, 1997; Adnan, an interview on December 12, 2011).

This form of movement between K.H. Ahmad Sanusi of Pesantren Samsul Ulum Gunung Puyuh Sukabumi with K. H. Badruzaman from Pesantren Al-Falah Biru. Between K.H. Ahmad Sanusi and K.H. Badruzaman, both have the same vision for the joint activities of the movement against colonial practices.

Diagram 7

Pesantren Networking based on Movement visionand Struggle against the colonialism between Pesantren Samsul Ulum Gunung Puyuh and Pesantren Al-Falah Biru Garut

Pesantren Samsul Ulum Gunung Puyuh Sukabumi (K. H. Ahmad Sanusi)

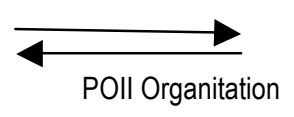

Pesantren Al-Falah Biru Garut

(K. H. Badruzaman)

Source: Wanta, 1997: 23; Ikyan, interview on Desember 12, 2011; Badruzaman, 2011: 243; Adnan, interview on Desember 13 , 2012 ; Arifin, 2011; Hanif, interview on July 28, 2011).

In addition to K.H. A. Sanusi of Pesantren Samsul Ulum, K.H. Badruzaman from Pesantren AlFalah Biru has the same vision on the activities of the movement and the struggle against invaders by Kiyai Mustafa Kamil, head of Pesantren Bojong Melati. In political life and organization, K.H. Badruzzaman the Kiyai Mustafa Kamil, both active in the organization of the SI Party of Indonesia (PSII) and Al-Muwafaqoh established in 1933 as a forum for the voice of Muslims in order to unite the clergy is in Garut to expel the Dutch invaders. In the SI party organizations Indonesia (PSII) Kiyai Mustafa Kamil as chairman PSII, while KH Badruzaman an active member of the organization supporting Garut PSII. While the organization of al-Muwafaqoh, Kiyai Mustafa Kamil and $\mathrm{KH}$ Badruzaman both are core board, as chairman and vice chairman of the organization of Al-Muwafaqoh (Badruzaman, 2011).

That involvement K.H. Badruzaman in the activities of the movement and struggle of opposition to the Dutch Government. At the time of independence, in accordance with the needs of the people, 
Masjumi a congress in Yogyakarta on 7-8 November 1945, decided to increase military organization Hizbullah than other woods. The congress was decided to form a paramilitary Sabilillah.

As a follow up to that, then the Muslims rise up against the invaders. They are many who joined the army-army people. Similarly, members of Tarekat Tijaniyah Garut. Under the command and guidance of K.H. Badruzzaman, they joined the army of Hizbullah and Sabilillah. For Hizbullah K.H. Badruzaman appoint the youth aged 17-25 years, while he pointed to the Sabilillah appoint ajengan (kiyai) who became his student at Pesantren Al-Falah Biru. For the battalion chief was entrusted to Marko and Mahbub Ahmad Sofyan. While K.H. Badruzaman itself has a special force consisting of 40 people. They are not only trained military, but especially given the deeds-deeds aurad differentiated from other woods pupils, because itspotential (Hidayat, 2011).

While the Kiyai Mustafa Kamil of Pesantren Bojong, in the activities of the movement and the struggle against the invaders themselves to 1945 , he was known to be brave in the challenge the rules of the Dutch East Indies government and the Government of Occupied Japan. In his opinion, that the Dutch and the Japanese invaders are equally miserable people. Dutch East Indies government and the Government of Japan's occupation must be resisted and expelled. Therefore when Bung Tomo proclaimed jihad against the allies, Kiyai Mustafa Kamil went to Surabaya along with members of the army of people to join in the battle. He left with the troops lainnnya through Banjar, Yogya and Malang to participate attacking allies in Surabaya (Herlina et al., 2011).

Diagram 8

Pesantren Networking Based on Vision of Movementand Struggle Against Colonialism Pesantren Al-Falah Biru Garut and Pesantren Bojong Melati

\begin{tabular}{|c|c|c|}
\hline $\begin{array}{l}\text { Pesantren Al-Falah Biru Garut } \\
\text { (K.H. Badruzaman) }\end{array}$ & $\underset{\text { Al-Muwafaqoh Organitation }}{\longrightarrow}$ & $\begin{array}{c}\text { Pesantren Bojong Melati Tarogong Garut } \\
\text { (Kiyai Mustofa Kamil) }\end{array}$ \\
\hline
\end{tabular}

Pesantren Sukamanah and Pesantren Cipasung have a network in the struggle against the invaders as the K.H. Zainal Mustafa and Kiyai Ruhiyat been together in prison for the Netherlands. K.H. Zainal Mustafa during lectures frequently descended from the pulpit by the Dutch government stooge and detained with Kiyai Ruhiyat, head of Pesantren Cipasung. In between the two are often out of jail Tasikmalaya (Mohsin, 1996; Yahya, 2006).

Life in Prison for a second kiyai is not fun though apparently not a new thing. According lip D. Yahya (2006), Kiyai Ruhiyat on November 17, 1941 he was arrested on charges of inciting people and detained together with K.H. Zaenal Mustofa Sukamiskin in prison and both were released poada dated January 10, 1942. So for about seven weeks Kiyai Ruhiyat and K.H. Zainal Mustafa was in jail Sukamiskin, Bandung. However, less than a month and a half hose K.H. Zainal Mustafa as a Kiyai Ruhiyat his activities in opposition to the Netherlands with dozens of other woods Kyai that he was sent back to jail at the end of February 1942 Ciamis before the Japanese invasion of Java, and later released by the Government of Occupied Japan on March 31, 1942 (See also Muhsin, 1996).

This is the struggle between the network Pesantren Sukamanah and Cipasung government in its struggle against the Dutch East Indies. In between these two schools, both have the same vision to challenge the existence of the Government of the Dutch East Indies. Pesantren Sukamanah by K.H. Zainal Mustafa orientation directed through the motions, 
while Pesantren Cipasung through Kiyai Ruhiyat through education movement. According to Asep Fuad Tohir existence of two different orientations is basically a strategy drawn up by both. Although power has been transferred from the Government of the Netherlands East Indies to the Japanese occupation government attitudes and views of both the occupiers have not changed (Fuad, interview on September 2, 2011).

Diagram 9

Pesantren Networking Based on Vision of Movement and Struggle Against Colonialism Pesantren Sukamanah dan Pesantren Cipasung

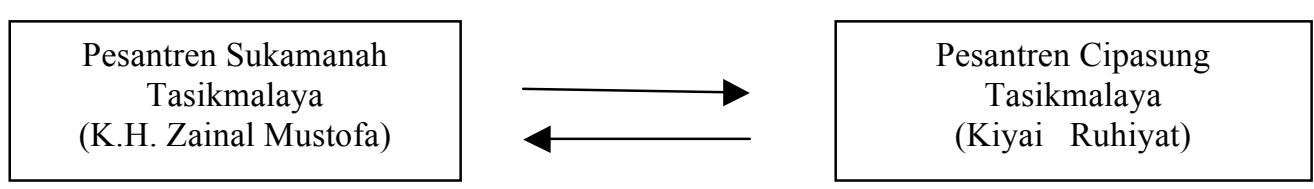

Organization of Nahdlatul Ulama against Governement of Hindia Belanda and Japanese Invador Source: Yahya, 2006; At-Tarmizi and Kalam, 2008; Hadi, Interview on January 18, 2010; Sahid, Interview on January 18, 2010.

\section{CONCLUSION}

The presence of schools in the region Priangan from 1800 until the end of the Japanese Occupation Government in 1945 has shown a significant amount of spread in the Garut, Tasikmalaya, Ciamis, Bandung, Sumedang, Cianjur, and Sukabumi as the Residency Priangan region. During the period Garut area there are 7 schools. In the area of Ciamis and Tasikmalaya are 7 and 11 schools. In the area of Bandung and Sumedang there are 17 and 3 schools. In the area there are Sukabumi and Cianjur each of the 3 schools. Thus, in the region there are at least 51 schools Priangan. Pesantren can be considered as great schools that have an influence on his time.

Based on the results of the study found that pesantren scattered Priangan in the 19th century up to the year 1945, many still have a relationship that encourages the formation of networks among schools. There are five forms of networking that describes the relationship inter-pesantren Priangan region.

First, inter-pesantren network formed by the relationship of science. In the most comprehensive pesantrens in the region Priangan like Pesantren Al-Falah Biru, Pangkalan and Keresek in Garut; Pesantren Gentur, Kandang Sapi, and Darul Falah Jambudipa in Cianjur; Pesantren Sukamiskin, Sirnamiskin, Ar-Rosyid Cibaduyut, Cijerah, Sindang Sari Al-Jawami, Cigondewa, Islam-Kiangroke, Baitul Arqam in London; Pesantren Miftahul Hoer, Darul Ulum, Cidewa/ Darussalam, Cijantung and Al-Fadhiliyah in Ciamis; Pesantren Samsul Uum in Sukabumi; Pesantren Pagelaran in Sumedang-Subang; Miftahul Huda Al-Azhar Citangkolo in Banjar; Pesantren Cintawana, Sukamanah, Sukahideung, Suryalaya, and As-Salam in Tasikmalaya, scientifically through books in the field of Tafsir, Tauhid, Fiqh / Usul Fiqh, Morals, and Language (Science Tools) still have a link with two schools located in the eastern parts of the island of Java is Pesantren Tebu Ireng, and Pesantren Bangkalan then empties the Syekh Nawawi Al-Bantani, and then the Syekh Khatib Sambas in Mecca. The existence of this scientific relationship occurs because the founders and successors of the pesantren had studied the previous kiyai or pesantren leaders of his time in the period from 1800 to 1945.

Second, the network among pesantren formed the basis of the relationship geneologically / family. Pesantren Sumur Kondang existence, Keresek, Gentur, and Cijawura is an example that the four 
schools still have a relationship geneologis because among the four extant father-child relationship, grandparents and grandchildren, and siblings.

Third, the network among pesantren formed the basis of the marital relationship. The existence of the marriage between family Pesantren Cipari with Cilame; between Pesantren Sukamiskin with Cijawura Bandung, and the Pesantren Al-Jawami Sindangsari with Pesantren Sukamiskin Bandung has become proof of marriage among pesantren network.

Fourth, among pesantren network formed by an association based on similarities in the development of a particular congregation. The appearance of the developing Pesantren Suryalaya Tarekat Qodiriyah wa Naqsyabandiyah followed by the appointment of representatives of his talqin in Bandung Dayeuhkolot Pesantren, Pesantren Cisayong, Salopa Pesantren, Pesantren Ciawi in Tasikmalaya, and Pesantren Cinambo in Talaga-Majalengka, and Pesantren Al-Falah-Biru that developed The congregation muqaddam Tijaniyah with his appointment at Pesantren Al-Falah, Darul Falihin, Al-Asyariyah Cimencek, Al-Hidayah, Al-Manar, and Singajaya is an example of the association between the schools based on the similarities in the development of the congregation.

Fifth, inter-pesantren network formed by equations vision in activities of the movement and the struggle against the invaders. The existence of alliances represented by the leaders of Pesantren Cipasung and Sukamanah Tasikmalaya (K.H.Ruhiyat and K.H. Zainal Mustopa); Pesantren Samsul Gunung Puyuh Sukabumi and Pesantren Ulum Al-Falah Biru (K.H. Ahmad Sanusi and KH Badruzzaman in POII), as well as Pesantren Al-Falah Biru and Pesantren Bojong Melati (K.H. Badruzzaman and K.H. Mustafa Kamil) in the organization PSII (Party Syarikat Islam Indonesia) and Al-Muwafaqah) who fought against the Netherlands and Japan has become evident that Islamic schools have the same vision in the activities of the movement and struggle practices against imperialism. 


\section{References}

\section{A. Written Source}

Anonym. "K.H. Ahmad Sanusi (1888-1950)," Intisabi, No. 01/April 2009 M/Rabiul Tsani 1430 H., P. 34. Bandung.

Arifin, Sahid. (2005). Selayang Pandang Menelusuri Perjalanan Hidup Macan Suryalaya; K.H. Abu Bakar Faqih bin R.A. Raksadinata (1880-1989) Khalifah Al-Mursyid Tarikat Qodiriyah Naqsyabandiyah di Masa Dua Kepemimpinan Abah Sepuh dan Abah Anom. (Jakarta: Yayasan Al-Qomariyah Mandiri,).

Arifin, Tajul. (2011). Biografi Naskah Sejarah Perjuangan Syaikhuna Badruzaman. Garut: Yayasan Pengembangan Pesantren Al-Falah Biru.

At-Tarmizi. Yoga Ad., Kalam, M. Yajid. K.H. Moh. (1999). Ilyas Ruhiat Ajengan Santun dari Cipasung; Membedah Sejarah Hidup dan Pemikiran Islam Keumatan. Bandung: Remaja Rosda Karya.

Badruzzaman, Ikyan. (2011). Syekh Ahmad Al-Tijani dan Tarekat Tijaniyah di Indonesia. Bandung: Pustaka Rahmat.

Basri, Hasan. (1997). Sejarah Timbulnya Pesantren Keresek. Keresek: Tanpa Penerbit.

Departemen Agama. (1986). Direktori Pesantren 1. Jakarta: Perhimpunan Pengembangan Pesantren dan Masyarakat (P3M)

Direktori Pesantren. (2001). Jakarta: Direktorat Jenderal Pembinaaan Kelembagaaan Agama Islam Direktorat Pembinaaan Perguruan Agama Islam Proyek Peningkatan Pesantren.

Dhofier, Zamaksari. (1982). Tradisi Pesantren. Jakarta: Lembaga Penelitian, Pendidikan dan Penerangan Ekonomi dan Sosial.

Garaghan, Gilbert J. (1946). A Guide to Historical Method. New York: Fordham University Press.

Gobbe, E. and Adriaanse, C. (1993). Nasihat-Nasihat C. Snouck Hurgronje Semasa Kepegawaiannnya kepada Pemerintah Hindia-Belanda 1889-1936. Jakarta: INIS.

Gottschalk, Louis. (1975). Mengerti Sejarah, Terj. Nugroho Notosusanto. Jakarta: Yayasan Penerbit Universitas Indonesia.

Haedar, Amin. (2004). Masa Depan Pesantren dalam Tantangan Modernitas dan Tantangan Kompleksitas Global. Jakarta: IRD Press,

Herlina, Nina et al. (2011). Perkembangan Islam di Jawa Barat. Bandung: Yayasan Masyarakat Sejarawan Indonesia Cabang Jawa Barat.

Hidayat, Asep Ahmad. (2011). "Gerakan Tarekat Tijaniyah di Jawa Barat (Rekonstruksi Ajaran Tasawuf dan Perkembangan Tarekat Syeikh Ahmad al-Tijani di Garut 1935-1949)". Laporan 
Penelitian. Bandung: Lembaga Penelitian Universitas Islam Negeri Sunan Gunung Djati Bandung.

Cakrabuana. (7 November 2011). Syarif Hidayatullah dan Kian Santang: Tiga Tokoh Penyebar Agama Islam di Tanah Pasundan" in http://sundaislam.wordpress.com/2008/04/04/cakrabuana-syarif-hidayatullah-dan-kiansantang.

Hurgronje, C. Snouck. (1888). Mekka. Leyden: Haag Martinus Nijhoff.

(1931) Mekka in The Latter Part of The 19'T Century; Daily Life, Custom and Learning The Moslims of The East-India-Archipelago. Translated By. J.H. Monahan. Leyden: Late E.J. Brill LTD Publisher and Printers and London: Luzac \& Co,.

(1890). De Djawa Te Mekka. Semarang: Sneldruk H. Van Alphen.

Kartodirdjo, Sartono et al.(1976) Sejarah Nasional Indonesia. Jilid III. Jakarta: Departemen Pendidikan dan Kebudayaan.

(1984)Pemberontakan Petani Banten 1888. Terj. Hasan Basari. Jakarta: Pustaka Jaya.

Mahduri, M. Annas et al. (2002). Pesantren dan Pengembangan Ekonomi Ummat; Pondok Pesantren al-Ittifaq dalam Perbandingan. Jakarta: Departemen Agama bekerjsama dengan Indonesian Institute for Civil Society.

Mas'udi, Masdar F.(1986) . Direktori Pesantren. Jakarta: Perhimpunan Pengembangan Pesantren dan Masyarakat.

Muhsin, Mohammad Fuad. (1996). Sekilas Riwayat Hidup dan Perjuangan Pahlawan Nasional K.H. Zaenal Musthafa. Tasikmalaya: Yayasan K.H. Zaenal Musthafa

Mulyati, Sri. (2004). "Tarekat Qodiriyah wa Naqsyabandiyah; Tarekat Temuan Tokoh Indonesia" in Sri Mulyati (Ed), Mengenal dan Memahami Tarekat-tarekat Muktbarah di Indonesia. Jakarta: Prenada Media.

Praja, Juhaya S. (1990). "TQN Pondok Pesantren Suryalaya dan Perkembangannnya pada masa Abah Anom" in Harun Nasution (Ed), Thoriqot Qodiriyyah Naqsabandiyah: Sejarah, Asal-usul dan Perkembangannnya; Kenangan-kenangan Ulang Tahun Pondok Pesantren Suryalaya ke- 85 (1905-1990). Tasikmalaya: Institut Agama Islam Latifah Mubarakiyah.

dan Anwar, Zainal Abidin. (1990). "Pengaruh TQN Pondok Pesantren Suryalaya di dalam dan di luar Negeri" in Harun Nasution (Ed), Thoriqot Qodiriyyah Naqsabandiyah: Sejarah, Asal-usul dan Perkembangannya; Kenangan-kenangan Ulang Tahun Pondok Pesantren Suryalaya ke- 85 (1905-1990). Tasikmalaya: Institut Agama Islam Latifah Mubarakiyah

Rosidi, Ajip et al. (2000). Ensiklopedi Sunda; Alam, Manusia dan Budaya Termasuk Budaya Cirebon dan Betawi. Jakarta: Pustaka Jaya 
Rufaidah, Eva. (2003). Perkembangan Kehidupan Keagamaaan Masyarakat Muslim Perkotaan Bandung 1906-1930-an. Tesis. (Yogyakakarta: Program Pascasajana Universitas Gadjah Mada.

Sanusi, Ahmad. (1990). "Abah Sepuh dan Pembentukkan TQN Pondok Pesantren Suryalaya" dalam Harun Nasution (ed.), Thoriqot Qodiriyyah Naqsabandiyah: Sejarah, Asal-usul dan Perkembangannya; Kenangan-kenangan Ulang Tahun Pondok Pesantren Suryalaya ke- 85 (1905-1990). Tasikmalaya: Institut Agama Islam Latifah Mubarakiyah.

Siswanto, H.B. et al. (2005). Satu Abad Pondok Pesantren Suryalaya: Peralanan dan Pengabdian 1905-2005. Tasikmalaya: Yayasan Serba Bakti Pondok Pesantren Suryalaya.

Sulasman. (2007). K.H. Ahmad Sanusi: (1889-1950); Berjuang dari Pesantren hingga Parlemen. Bandung: Pimpinan Wilayah Persatuan Ummat Islam (PUI) Jawa Barat.

(2008) "K.H. Ahmad Sanusi: Berjuang dari Pesantren hingga Parlemen" in Irfan Safrudin (ed.), Ulama-ulama Perintis: Biografi Pemikiran dan Keteladanan. Bandung: MUI Kota Bandung.

Suprapto, M. Bibit. (2009). Ensiklopedi Ulama Nusantara; Riwayat Hidup, Karya dan Sejarah Perjuangan 157 Ulama Nusantara. Jakarta: Gelegar Media Indonesia

Verbal Diet Boek Heet Nahratoe'ddhargam (1919) (De Gebriedende Leeuwenstem) Dienende tot Wering van de Aanvallen door Verach'telijk Menschen Gericht Tegen de S.I. door Sjeich Ahmad bin A'ssanoesi bin Abdoerrahim. Leiden: Koninklijk Institute voor Taal-, Landen Volkenkunde,).

Wanta, S. (1997). K.H. A. Halim Iskandar dan Pergerakannya. Majalengka: Pengurus Besar Persatuan Umat Islam Majlis Pengajaran.

(1997) K.H. Ahmad Sanusi dan Perjoangannya. (Majalengka: Pengurus Besar Persatuan Ummat Islam Majlis Pengajaran,).

Yahya, lip D. (2006). Ajengan Cipasung; Biografi K.H. Moh. Ilyas Ruhiat. Yogyakarta: Pustaka Pesantren

Yatim, Badri. (1997). Peradaban Islam. Jakarta: Rajawali Pers bekerja sama dengan Lembaga Studi Islam dan Kemasyarakatan.

\section{B. Unwritten Source}

Abdullah, Muhammad ( \pm 66 years old). The leader of Pesantren Darul Ulum. Interview, Ciamis, January 30, 2010.

Abdurrohim, Munawir (54 years old). The leader of Pesantren Miftahul Huda Al-Azhar Citangkolong Banjar.Interview, Banjar. January 19, 2010.

Adnan (49 years old). The child of Syekh Badruzaman. Interview. Bandung, December 11, 2011.

Affandi, Usman (35 years old). Interview. Garut, July 28, 2011. 
Ainusyamsi, Fadhil Yani (45 years old). The grandchild of Ahmad Fadhil. Interview. Ciamis, Agustus 18, 2011.

Anam, Choerul (50 years old). The leader of Pesantren Darul Falah Jambudipa. Interview, Cianjur, Februari 12, 2010.

Aziz, Abdul (60 years old). The leader of Pesantren Sukamiskin. Interview, Bandung, July 15 2011.

Bunyamin, Amin (64 tahun). The leader of Pesantren Cipari. Interview. Garut, July 28, 2011.

Fuad, Acep Tohir (62 years old). The leader of Pesantren Sukamanah. Interview, Tasikmalaya, September 2, 2011.

Ganis ( \pm 35 tahun). The leader of Pesantren Darussalam. Interview. Garut, January 13, 2010.

Hadi, Abdul (78 tahun). The life witness of K.H. Ruhiyat dan K.H. Mohammad Ilyas Ruhiat. Interview. Tasikmalaya, January 18, 2010.

Halim, Abdul ( \pm 54 tahun). The Take as son K.H. Yusuf Taujiri. Interview. Garut, January 14, 2010.

Hamid, Imang Abdul (60 years old ). The leader of Pesantren Sindangsari Al-Jawami Cileunyi. Interview. Bandung, July 15, 2011.

Hanif (40 years old). The bringer up of Pesantren Al-Falah Biru. Interview. Garut, July 28, 2011.

Haris, lir Abdul (38 years old). Interview. Bandung, December 14, 2011.

Hassan, Eded ( \pm 63 years old). The grandchild from the first child founder Pesantren Cintawana. Interview. Tasikmalaya, January 18, 2010.

Ikyan (53 years old). The leader of Pesantren Al-Falah Biru. Interview. Bandung, December 12, 2011.

Ismatullah, M.A.H. ( \pm 25 years old). Great grandchild of Muhammad Said, Founder of Pesantren Gentur Jambudipa Warungkondang. Interview, Cianjur, Februari 12, 2010.

Komar, Ahmad (75 years old). The life witness of K.H. Muhyidin and K.H. Oom Abdul Qoyim Muhyidin. Interview. Subang, March 13, 2010.

Komarudin, Buldan (60 years old). The Leader of Pesantren Darul Falah Jambudipa. Interview. Cianjur, Februari 12, 2010.

Lilis Abdul Halim ( \pm 48 years old ). The daughter of K.H. Yusuf Taujiri. Interview Garut, January 14,2010

Lilis Hasan Basri ( \pm 60 years old). The wife of Hasan Basri, fifth leader of Pesantren Keresek. Interview. Garut, January, 13, 2010. 
Mansur, Fadlil Munawar ( \pm 48 years old). The grandchild of Ahmad Fadhil. Interview. Ciamis, Februari 19, 2010.

Muhyidin, Dandy Sobron (33 years old). The grandchild of. Muhyidin. Interview. Subang, March 13, 2010.

Munandar (40 years old). The grandchild of Opo Mustofa. Interview. Cianjur, February 12, 2010.

Rustam, Atam ( \pm 52 years old). The grandchild of. Zaenal Mustofa. Interview. Tasikmalaya, January 18, 2010.

Sahid, H. (74 years old). The life witness of Ruhiyat and K.H. Mohammad Ilyas Ruhiat. Interview. Tasikmalaya, January 18, 2010.

Sanusi, Anwar (55 years old). The leader of Pesantren Asyropudin. Interview, Sumedang, July 30, 2011.

Solehudin, Dedi Mohammad ( \pm 34 years old). The leader of Pesantren Miftahul Hoer. Interview. Ciamis, January 30, 2010.

Sudjai, Ahmad ( \pm 40 years old). The leader of Pesantren Cintawana. Interview, Tasikmalaya, Januari 18, 2010.

Sulaeman, H.A.W. ( \pm 77 years old). The life witnes of K.H. Muhyidin and K.H. Oom Abdul Qoyim Muhyidin. Interview, Subang, March 13, 2010.

Tohir, Muhammad ( \pm 45 years old). The leader of Pesantren Al-Fadhiliyah. Interview. Ciamis, January 30, 2010.

Wadud, Dudung Abdul (65 years old)

The grandchild founder of Pesantren Cibeunteur, and fifth leader from Pesantren Cibeunteur. Interview. Banjar, January 19, 2010. 